\title{
Investigating the role of innovative behavior in mediating the effect of transformational leader- ship and talent management on performance
}

\section{Widodo Widodo $^{\mathrm{a}^{*}}$ and Mawarto Mawarto ${ }^{\mathrm{b}}$}

${ }^{a}$ Faculty of Education and Social Sciences of Indraprasta University, Jakarta, Indonesia ${ }^{b}$ Bumiputra College of Economics Science, Jakarta, Indonesia

\section{H R O N I C L E \\ A B S T R A C T}

Article history:
Received: February 15, 2020
Received in revised format:
March 162020
Accepted: March 16, 2020
Available online:
March 16, 2020
Keywords:
Transformational leadership
Talent management
Innovative behavior
Performance

The research investigates the role of innovative behavior in mediating the effect of transformational leadership and talent management on the lecturer's performance of private higher education in Indonesia. Samples of this research are 230 lecturers selected by purposive sampling. Data were obtained by spreading questionnaires and analyzing with path analysis using supporting descriptive statistics. The results confirm that transformational leadership and innovative behavior had significant direct effects on performance, transformational leadership and talent management had significant direct effects on innovative behavior, transformational leadership and talent management had significant indirect effects on performance mediating by innovative behavior, and talent management did not have any significant direct effect on performance. A fit research model has been achieved about the effects of transformational leadership and talent management performance by mediating innovative behavior but requires verification through further research, especially to verify the effect of talent management on performance.

\section{Introduction}

The issue of employee performance always receives special attention from academics, researchers, and practitioners. It is inseparable from the vitality of employees for organizational performance. As study Vosloban (2012) shows, employee performance largely determines organizational growth. That means that organizations that grow and have high competitiveness are the ones with optimal employee performance. In other words, organizations that fail to grow are those that fail to manage their employees' performance well. This is no exception for educational organizations, including higher education. As reported by various national and international ranking institutions, most private universities in Indonesia have not been able to demonstrate their existence. At the national level, based on the ranking of the Ministry of Research, Technology and Higher Education of The Republic of Indonesia in 2019, none of the 3940 private higher education in Indonesia was ranked in the top 10. Telkom University as a private university which was ranked the best (14), at the international level only ranks 533 in Asia and 1906 in the world version of Webometrics. This indicates that the performance of the human resources of private higher education in Indonesia, especially lecturers as the main actors in the teaching and research process of higher education, has not shown optimal performance.

\section{Theoretical framework and hypothesis development}

\subsection{Performance}

Performance is a set of tasks or work behaviors designed to accomplish a job requirements or realize organizational goals (Ivancevich et al., 2014; Byars et al., 2016; Colquitt et al., 2015). Behavior in this context, according to Brumbrach as a quote 
Armstrong (2009), not just the instruments for results, but also outcomes in their own right - the product of mental and physical effort applied to tasks - and can be judged apart from results. Therefore, performance can be viewed from a perspective on contextual performance, which includes those behaviors that contribute to the organization's effectiveness by providing a good environment in which task performance can occur, such as: persisting with enthusiasm and exerting extra effort as necessary to complete one's task activities successfully; volunteering to carry out task activities that are not formally part of the job; helping and cooperating with others; following organizational rules and procedures; and endorsing, supporting, and defending organizational objectives (Aguinis, 2013).

\subsection{Transformational Leadership}

Performance, among others, is influenced by transformational leadership. The transformational leadership model until now has remained popular because it has resulted in significant organizational changes. It is inseparable from practice transformational leadership which has emphasized on intrinsic motivation, trust, commitment and loyalty of followers (Kreitner \& Kinicki, 2010). Several studies also reported that transformational leadership affects performance, for example, Gooty et al. (2009), Jyoti and Bhau (2015), Kala'lembang et al. (2015), Chen et al. (2018), Apoi and Latip (2019), Abuzaid, Al-Ma'aitah et al. (2019), and Chandrasekara (2019). According to Brown and Keeping (2005), transformational leadership is characterized by the ability of leaders to articulate a shared vision of the future, intellectually stimulate employees, and pay attention to individual differences in employees. Beside, transformational leadership is also characterized by leader behavior that motivates people to transcend their interests for the good of the group; confidence, need to influence others, and hold strong attitude that their beliefs and ideas are correct; and able to influence others by using charisma, paying attention, to followers, and stimulating others (Bateman \& Snell, 2015; Aamodt, 2013; Ivancevich, Kanopaske, \& Matteson, 2016). Bass and Avolio (1990) identified four indicators of transformational leadership, namely: idealized influence, inspirational motivation, intellectual stimulation, and individualized consideration. Thus, it can be hypothesized:

$\mathrm{H}_{1}$ : Transformational leadership has a direct effect on performance.

\subsection{Talent Management}

The performance is also influenced by talent management. Talent management is a very important factor in efforts to help organizational performance (Collings \& Mellahi, 2009). The results of research by Kehinde (2012), Auranzeb and Bhutto (2016), Ndolo, Kingi, and Ibua (2017), Agbaeze, Monyei, and Agu (2017), Son, Park, Bae, and Ok (2018), Supraptiningsih, Payangan, Brasit, and Mardiana (2018), Hitu (2018), and Bibi (2019) show that talent management influences performance. Talent management is a set of processes designed to ensure that every employee at all levels of work is at its peak potential and there is sufficient flow of employees into jobs throughout the organization to contribute to the sustainability of the organization's competitiveness (Redford, 2005; Kesler \& Pascal, in Lewis \& Heckman, 2006; Collings \& Mellahi, 2009). That means talent management is a strategic activity aligned with the firm's business strategy that aims to attract, develop, and retain talented employees at each level of the organization (Hatum, 2010). Talent management has nine elements, namely: the resourcing strategy, attraction, and retention policies and programs, talent audit, role development, talent relationship management, performance management, total reward, career management, and creating the best place to work (Smilansky, 2005). Thus, it can be hypothesized:

\section{$\mathrm{H}_{2}$ : Talent management has a direct effect on performance.}

\subsection{Innovative Behavior}

The performance also influenced by innovative behavior. The results of the study which concluded that innovative behavior affects performance, including among others conducted by Janssen, van de Vliert, and West (2004), Marques and Ferreira (2009), Gunday, Ulusoy, Kilic, and Alpkan (2011), Aryee, Walumbwa, Zhou, and Hartnell (2012), Bhanugopan, van der Heijden, and Farrell (2017), Schuh, Zhang, Morgeson, Tian, and van Dick (2018), Shanker, Rizki, Parashakti, and Saragih (2019). Innovative behavior is an innovation that is carried out individually. According to Scott and Bruce, as quoted by Cingöz and Akdo (2011), individual innovation begins with the decline of ideas, the promotion of ideas towards potential incorporation, the realization of ideas by producing a prototype or innovation model that can be felt, and the peak is applied in work roles, groups, or organizations overall. In order words, innovative behavior is "intentional creation, introduction, and application of new ideas within a work role, group or organization, to benefit role performance, the group, or the organization" (Janssen, in Shih \& Susanto, 2011: 113). According to Carmeli, Meitar and Weisberg (2006: 78), innovative behavior is "multiple-stage process in which an individual recognizes a problem for which she or he generates new (novel or adopted) ideas and solutions, works to promote and build support for them, and produces an applicable prototype or model for the use and benefit of the organization or parts within it." Kleysen and Street (2001) identify five indicators of innovative behavior scale, namely: opportunity exploration, generativity, informative investigation, championing, and application. Thus, it can be hypothesized:

$\mathrm{H}_{3}$ : Innovative behavior has a direct effect on performance.

Innovative behavior besides influencing organizational commitment is also influenced by transformational leadership and talent management. The results of research carried out by Park, Moon, and Hyun (2014), Han, Seo, Yoon, and Yoon (2016), 
Bednall, Rafferty, Shipton, Sanders, and Jackson, (2018). Ahmad, Easa, and Mostapha (2019) showed that transformational leadership influences innovative behavior. Thus, it can be hypothesized:

$\mathrm{H}_{4}$ : Transformational leadership has a direct effect on innovative behavior.

Several studies conducted by Khaki, Khanzadeh, and Rad (2017), Olaka, Okafor, and Ulo (2018), Riaz, Xu, and Hussain (2018) showed that talent management has a direct effect on innovative behavior. Thus, it can be hypothesized:

$\mathrm{H}_{5}$ : Talent management has a direct effect on innovative behavior.

From the various results of the research above it can be seen that innovative behavior mediates the effect of transformational leadership and talent management on performance, therefore it can be hypothesized:

$\mathrm{H}_{6}$ : Transformational leadership has an indirect effect on performance by mediating innovative behavior.

$\mathrm{H}_{7}$ : Talent management has an indirect effect on performance by mediating innovative behavior.

\section{Research Methods}

This research uses a quantitative approach with a survey method. The survey involved a research sample of 230 permanent lecturers of private higher education in Indonesia spread across 10 provinces determined by purposive sampling based on certain characteristics (Widodo, 2019), namely permanent lecturers. The number of samples is by following the criteria of Hair et al. (2010) that good sample size is five to ten times the number of indicators (observations) of all research variables. The number of indicators (observations) of the four latent variables in this study is 23 , so if multiplied by ten $=230$. The details: four indicators of transformational leadership variables, namely idealized influence (II), inspirational motivation (IM), intellectual stimulation (IS), and individualized consideration (IC) (Bass \& Avolio, 1990), nine indicators of talent management variables, namely: the resourcing strategy (RS), attraction, retention policies and programs (ARPP), talent audit (TA), role development (RD), talent relationship management (TRM), performance management (PM), total reward (TR), career management (CM), and creating the best place to work (CBPW) (Smilansky, 2005), five indicators of innovative behavior variables, namely: opportunity exploration (OE), generativity (Gen), informative investigation (II), championing (Ch), and application (Ap) (Kleysen \& Street, 2001), and five indicators of performance variables, namely: persisting with enthusiasm and exerting extra effort as necessary to complete one's task activities successfully (EEE); volunteering to carry out the task activities that are not formally part of the job (VANJ); helping and cooperating with others (HCO); following organizational rules and procedures (FORP); and endorsing, supporting, and defending organizational objectives (ESD) (Aguinis, 2013). The data was collected by a questionnaire in the form of a Likert scale model with five alternative answers: strongly disagree, disagree, neutral, agree, and strongly agree. The questionnaire was made by researchers themselves based on the theoretical indicators of the experts. Transformational leadership questionnaire consists of 12 items with alpha coefficient $=.980$, talent management consists of 18 items with alpha coefficient $=.982$, innovative behavior consists of 10 items with alpha coefficient $=.893$, and performance consists of 10 items with alpha coefficient $=.899$. Data analysis using the path analysis and to test the significance of the path coefficient it uses a t-test supported by descriptive statistics.

\section{Research Result}

The results of the descriptive statistical analysis for the four research variables are presented as followed:

Table 1

Descriptive Statistics

\begin{tabular}{|c|c|c|c|c|c|}
\hline & & Transformational Leadership & Talent Management & Innovative Behavior & Performance \\
\hline$\overline{\mathrm{N}}$ & Valid & 230 & 230 & 230 & 230 \\
\hline & Missing & 0 & 0 & 0 & 0 \\
\hline Mean & & 48.16 & 73.16 & 40.82 & 41.87 \\
\hline Median & & 48.00 & 73.00 & 41.00 & 41.00 \\
\hline Mode & & 48 & 72 & 40 & 40 \\
\hline Std. Deviation & & 9.526 & 12.540 & 5.707 & 4.617 \\
\hline Variance & & 90.744 & 157.245 & 32.569 & 21.316 \\
\hline Range & & 48 & 58 & 25 & 30 \\
\hline Minimum & & 12 & 32 & 25 & 20 \\
\hline Maximum & & 60 & 90 & 50 & 50 \\
\hline Sum & & 11076 & 16827 & 9388 & 9631 \\
\hline
\end{tabular}

As shown in Table 1, the mean values of the four variables from the lowest to the highest in succession are innovative behavior (40.82), performance (41.87), transformational leadership (48.16) and talent management (73.16). The correlational analysis as summarized in Table 2 shows most indicators on each variable have significant relationships with the indicators of the other variables at level $\mathrm{p}<.05$, except the relationship between FORP and II (.12); FORP and IM (.10), EEE and TA (.10), EEE and TR (.07); and EEE and CM (.11). The results of hypothesis testing with path analysis of the effects of transformational leadership and talent management on innovative behavior and performance are visualized in Fig. 1 and Fig. 2 and summarized in Table 3. 


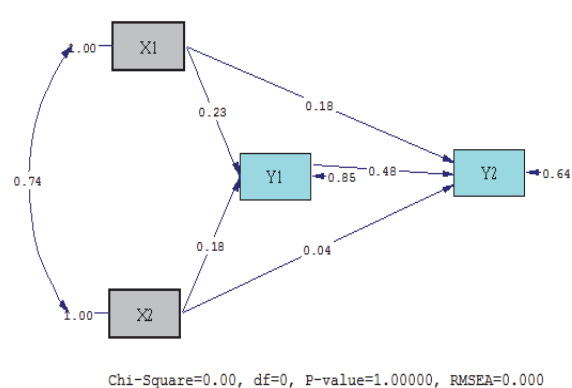

Fig. 1. Path Coefficients

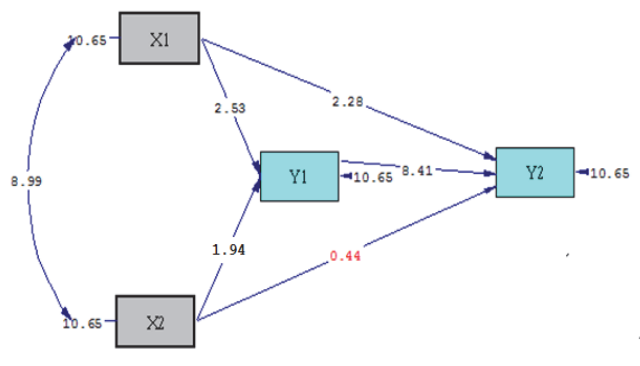

Chi-Square $=0.00, d f=0, P-$ value $=1.00000$, RMSEA $=0.000$

Fig. 2. $T$ Value

Table 2

Correlation matrix of indicators

\begin{tabular}{|c|c|c|c|c|c|c|c|c|c|c|c|c|c|c|c|c|c|c|c|c|c|c|c|}
\hline & 1 & 2 & 3 & 4 & 5 & 6 & 7 & 8 & 9 & 10 & 11 & 12 & 13 & 14 & 15 & 16 & 17 & 18 & 19 & 20 & 21 & 22 & 23 \\
\hline \multicolumn{24}{|c|}{ Transformational Leadership } \\
\hline 1. II & 1.00 & & & & & & & & & & & & & & & & & & & & & & \\
\hline 2. IM & $.88^{*}$ & 1.00 & & & & & & & & & & & & & & & & & & & & & \\
\hline 3. IS & $.84^{*}$ & $.88^{*}$ & 1.00 & & & & & & & & & & & & & & & & & & & & \\
\hline \multicolumn{24}{|l|}{ Talent Management } \\
\hline 5. RS & $.60^{*}$ & $.62^{*}$ & $.63^{*}$ & $.58^{*}$ & 1.00 & & & & & & & & & & & & & & & & & & \\
\hline 6. ARPP & $.67 *$ & $.68^{*}$ & $.70^{*}$ & $.61^{*}$ & $.79 *$ & 1.00 & & & & & & & & & & & & & & & & & \\
\hline 7. TA & $.62^{*}$ & $.62^{*}$ & $.64^{*}$ & $.58^{*}$ & $.82^{*}$ & $.83^{*}$ & 1.00 & & & & & & & & & & & & & & & & \\
\hline 8. RD & $.65^{*}$ & $.65^{*}$ & $.66^{*}$ & $.56^{*}$ & $.78^{*}$ & $.82^{*}$ & $.87^{*}$ & 1.00 & & & & & & & & & & & & & & & \\
\hline 9. TRM & $.68^{*}$ & $.68^{*}$ & $.67^{*}$ & $.61^{*}$ & $.76^{*}$ & $.80^{*}$ & $.78^{*}$ & $.90^{*}$ & 1.00 & & & & & & & & & & & & & & \\
\hline 10. PM & $.67 *$ & $.68^{*}$ & $.68^{*}$ & $.60^{*}$ & $.74 *$ & $.73^{*}$ & $.78 *$ & $.85^{*}$ & $.89^{*}$ & 1.00 & & & & & & & & & & & & & \\
\hline 11. $\mathrm{TR}$ & $.54 *$ & $.52^{*}$ & $.60^{*}$ & $.55^{*}$ & $.68^{*}$ & $.63^{*}$ & $.72^{*}$ & $.78^{*}$ & $.77 *$ & $.83^{*}$ & 1.00 & & & & & & & & & & & & \\
\hline 12. CM & $.65^{*}$ & $.61^{*}$ & $.65^{*}$ & $.57 *$ & $.74 *$ & $.74 *$ & $.78^{*}$ & $.85^{*}$ & $.82 *$ & $.83 *$ & $.83^{*}$ & 1.00 & & & & & & & & & & & \\
\hline 13. CBPW & $.71 *$ & $.68^{*}$ & $.70^{*}$ & $.60^{*}$ & $.78^{*}$ & $.75^{*}$ & $.78^{*}$ & $.83^{*}$ & $.83 *$ & $.84^{*}$ & $.79^{*}$ & .88 & 1.00 & & & & & & & & & & \\
\hline \multicolumn{24}{|l|}{ Innovative Behavior } \\
\hline 14. OE & $.15^{*}$ & $.16^{*}$ & $.29^{*}$ & $.27 *$ & $.17^{*}$ & $.21^{*}$ & $.17 *$ & $.17^{*}$ & $.13^{*}$ & $.14^{*}$ & $.16^{*}$ & $.17^{*}$ & $.17 *$ & 1.00 & & & & & & & & & \\
\hline 15. Gen & $.16^{*}$ & $.13^{*}$ & $26^{*}$ & $.27 *$ & $.19 *$ & $.24 *$ & $.25 *$ & $.24^{*}$ & $.17 *$ & $.20^{*}$ & $.25^{*}$ & $.18^{*}$ & $.19 *$ & $.61^{*}$ & 1.00 & & & & & & & & \\
\hline 16. II & $.22^{*}$ & $.24^{*}$ & $.30^{*}$ & $.36^{*}$ & $.17^{*}$ & $.27^{*}$ & $.23^{*}$ & $.24^{*}$ & $.19 *$ & $.19^{*}$ & $.23^{*}$ & $.19 *$ & $.21 *$ & $.54^{*}$ & $.70^{*}$ & 1.00 & & & & & & & \\
\hline 17. $\mathrm{Ch}$ & $.32 *$ & $.27^{*}$ & $.37^{*}$ & $.33^{*}$ & $.26^{*}$ & $.35 *$ & $.32 *$ & $.34^{*}$ & $.34 *$ & $.34^{*}$ & $.32^{*}$ & $.31 *$ & $.36^{*}$ & $.35^{*}$ & $.53^{*}$ & $.51^{*}$ & 1.00 & & & & & & \\
\hline \multirow{2}{*}{\multicolumn{24}{|c|}{$\begin{array}{l}\text { 18. Ap } \\
\text { Performance }\end{array}$}} \\
\hline & & & & & & & & & & & & & & & & & & & & & & & \\
\hline 19. EEE & $.18^{*}$ & $.21^{*}$ & $.26^{*}$ & $.19^{*}$ & $.13^{*}$ & $.19^{*}$ & .10 & $.16^{*}$ & $.13 *$ & $.16^{*}$ & .07 & .11 & $.15^{*}$ & $.24^{*}$ & $.15^{*}$ & $.20^{*}$ & $.33^{*}$ & .10 & 1.00 & & & & \\
\hline 20. VANJ & $.26 *$ & $.26^{*}$ & $.33^{*}$ & $.34 *$ & $.26^{*}$ & $.25 *$ & $.26^{*}$ & $.28^{*}$ & $.28^{*}$ & $.27 *$ & $.25^{*}$ & $.23 *$ & $.26 *$ & $.40^{*}$ & $.39 *$ & $.34^{*}$ & $.28^{*}$ & .35 & $.48^{*}$ & 1.00 & & & \\
\hline 21. $\mathrm{HCO}$ & $.25^{*}$ & $.19^{*}$ & $.31 *$ & $.26^{*}$ & $.27 *$ & $.28^{*}$ & $.31 *$ & $.33^{*}$ & $.29^{*}$ & $.28^{*}$ & $.27^{*}$ & $.27 *$ & $.33 *$ & $.40^{*}$ & $.41^{*}$ & $.34^{*}$ & $.27^{*}$ & $.32 *$ & $.35^{*}$ & $.74 *$ & 1.00 & & \\
\hline 22. FORP & .12 & .10 & $.24 *$ & $.18^{*}$ & $.15^{*}$ & $.18 *$ & $.20 *$ & $.15^{*}$ & $.13 *$ & $.15^{*}$ & $.21^{*}$ & $.14 *$ & $.20 *$ & $.36^{*}$ & $.44 *$ & $.40^{*}$ & $.28^{*}$ & $.35 *$ & $.19^{*}$ & $.40^{*}$ & $.47^{*}$ & 1.00 & \\
\hline 23. ESD & $.36^{*}$ & $.34^{*}$ & $.43^{*}$ & $.42^{*}$ & $.28^{*}$ & $.35^{*}$ & $.38^{*}$ & $.32^{*}$ & $.26^{*}$ & $.29^{*}$ & $.24^{*}$ & $.23 *$ & $.31 *$ & $.41^{*}$ & $.45^{*}$ & $.36^{*}$ & $.37^{*}$ & $.42^{*}$ & $.25^{*}$ & $41^{*}$ & $.46^{*}$ & $.59 *$ & 1.00 \\
\hline
\end{tabular}

Table 3

Summary of path coefficients and t values

\begin{tabular}{|c|c|c|c|}
\hline Hypothesis & Path Coefficients & T Value & Hypothesis Testing \\
\hline $\mathrm{H}_{1}$ : Transformational leadership $\left(\mathrm{X}_{1}\right)$ on Performance $\left(\mathrm{Y}_{2}\right)$ & $.18^{*}$ & 2.28 & Supported \\
\hline $\mathrm{H}_{2}$ : Talent management $\left(\mathrm{X}_{1}\right)$ on Performance $\left(\mathrm{Y}_{2}\right)$ & $.04^{\mathrm{ns}}$ & .44 & Not Supported \\
\hline $\mathrm{H}_{3}$ : Innovative behavior $\left(\mathrm{Y}_{1}\right)$ on Performance $\left(\mathrm{Y}_{2}\right)$ & $.48 * *$ & 8.41 & Supported \\
\hline $\mathrm{H}_{4}$ : Transformational leadership $\left(\mathrm{X}_{1}\right)$ on Innovative behavior $\left(\mathrm{Y}_{1}\right)$ & $.23 * *$ & 2.53 & Supported \\
\hline $\mathrm{H}_{5}:$ Talent management $\left(\mathrm{X}_{2}\right)$ on Innovative behavior $\left(\mathrm{Y}_{1}\right)$ & $.18^{*}$ & 1.94 & Supported \\
\hline $\begin{array}{l}\mathrm{H}_{6} \text { : Transformational leadership }\left(\mathrm{X}_{1}\right) \text { on Performance by mediating Inno- } \\
\text { vative behavior }\left(\mathrm{Y}_{1}\right)\end{array}$ & $.11 * *$ & 2.43 & Supported \\
\hline $\begin{array}{l}\mathrm{H}_{7} \text { Talent management }\left(\mathrm{X}_{2}\right) \text { on Performance by mediating Innovative be- } \\
\text { havior }\left(\mathrm{Y}_{1}\right)\end{array}$ & $.09 *$ & 1.89 & Supported \\
\hline
\end{tabular}

$* * \mathrm{p}<.01$

The test results in Table 3 show that all hypotheses were supported, except talent management on performance. Transformational leadership and innovative behavior had a significant direct effect on performance. Transformational leadership and talent management had a significant direct effect on innovative behavior. Transformational leadership and talent management had a significant indirect effect on performance by mediating innovative behavior. In Fig. 1 and Fig. 2, the test results of the model with goodness of fit statistics show the significant or Chi-Square $=0.000, \mathrm{df}=0, \mathrm{p}$-value $=1.00000>.05$ and RMSEA $=.000<.08$, so that the model tested is fit. That means the theoretical model being tested is supported by empirical data.

\section{Discussion}

\subsection{Direct Effect of Transformational Leadership on Performance}

The results of this study have proven that transformational leadership had a positive and significant direct effect on performance. This indicates that the transformational leadership of effective university managers can have implications for improving lecturer performance. In practice, when a leader has and can apply idealized influence, inspirational motivation, intellectual stimulation, and individualized consideration (Bass \& Avolio, 1990) optimally, then the leader can inspire and influence his subordinates, so that subordinates willingly do the work as much as possible, such as: persisting with enthusiasm and exerting extra effort as necessary to complete one's task activities successfully; volunteering to carry out task activities that 
are not formally part of the job; helping and cooperating with others; following organizational rules and procedures; and endorsing, supporting, and defending organizational objectives (Aguinis, 2013). This trend is also no exception in private higher education in Indonesia, especially in the context of the causal relationship between transformational leadership and the lecturer's performance. The results of previous studies have also proven that transformational leadership have an influence on performance (e.g. Gooty et al., 2009; Jyoti \& Bhau, 2015; Kala'lembang et al., 2015; Chen et al., 2018; Apoi \& Latip, 2019; Abuzaid, et al., 2019; and Chandrasekara, 2019). Therefore, these findings are consistent, support, and confirm the results of previous studies that transformational leadership has a positive and significant direct effect on performance.

\subsection{Direct Effect of Talent Management on Performance}

The results of this study also revealed that talent management has not a direct effect on performance. This finding shows that talent management is not important for the lecturer's performance, so university managers are not important to consider talent management to improve lecturer performance. This finding is not in line with results of previous studies on the effect of talent management on performance by researchers in various countries and various industrial and occupational sectors (e.g. Kehinde, 2012; Auranzeb \& Bhutto, 2016; Ndolo, Kingi, \& Ibua, 2017; industrial and occupational sectors (e.g. Kehinde, 2012; Auranzeb \& Bhutto, 2016; Ndolo et al., 2017; Monyei, \& Agu, 2017; Son, et al., 2018; Supraptiningsih, et al., 2018; Hitu, 2018; and Bibi, 2019) so that it can be the antithesis that results in research gaps that require further verification.

\subsection{Direct Effect of Innovative Behavior on Performance}

The results of this study also indicate that innovative behavior has a positive and significant direct effect on performance. The results of this study also indicate that innovative behavior has a positive and significant direct effect on performance. This finding shows that innovative behavior can be relied upon to improve lecturer performance so that university managers not only need to provide the widest possible space or opportunity for lecturers to show their innovative behavior, but more than that also need to provide support for the growth of innovative behavior of lecturers, especially those related to activities: opportunity exploration, generativity, informative investigation, championing, and application (Kleysen \& Street, 2001). Such support, for example, can be in the form of training or workshops, or even just giving freedom to lecturers to conduct new experiments with supervision and financial support universities. This finding is as rigorous and confirms the results of previous studies that innovative behavior has a significant effect on performance (e.g. Janssen et al., 2004; Marques \& Ferreira, 2009; Gunday, et al., 2011; Aryee, et al., 2012; Bhanugopan et al., 2017; Schuh, et al., 2018; and Shanker, et al., 2019). Thus, these findings are consistent, support, and confirm the results of previous studies that innovative behavior has a positive and significant direct effect on performance.

\subsection{Direct Effect of Transformational Leadership on Innovative Behavior}

The results of this study also show that transformational leadership has a positive and significant direct effect on innovative behavior. This indicates that variations in the innovative behavior of lecturers can be influenced by the good or bad practice of transformational leadership that is applied in universities. This empirical fact is consistent with the reality of daily transformational leadership practices. Transformational leadership indicators such as idealized influence, inspirational motivation, intellectual stimulation, and individualized consideration (Bass \& Avolio, 1990) have a big influence on the growth of innovative behavior, including the innovative behavior of lecturers. This means that universities need to develop transformational leadership patterns that are more intense and massive so that the innovative behavior of lecturers grows optimally as capital for universities in building higher education competitiveness and producing high-quality graduates. This finding is appropriate and confirms the results of previous studies conducted by Park, Moon, and Hyun (2014), Han, et al. (2016), Bednall, et al. (2018), and Ahmad, Easa, and Mostapha (2019) show that transformational leadership influences innovative behavior. Thus, these findings are consistent, support, and confirm the results of previous studies that transformational leadership has a positive and significant direct effect on innovative behavior.

\subsection{Direct Effect of Talent Management on Innovative Behavior}

The results of this study also indicate that talent management has a positive and significant direct effect on innovative behavior. This finding illustrates that the good or bad talent management of the universities will have an impact on the lecturer's innovative behavior. This confirms the meaning that university managers need to manage the talents of lecturers as best they can, especially in terms of the resourcing strategy, attraction, and retention policies and programs, talent audits, role development, talent relationship management, performance management, total reward, career management and creating the best place to work (Smilansky, 2005) so that the innovative behavior of lecturers grow optimally so that universities can benefit from the growth of innovative behavior. This finding aligns and confirms previous research conducted by Khaki et al. (2017), Olaka et al. (2018), and Riaz et al. (2018) show that talent management has a direct effect on innovative behavior. Thus, these findings are consistent, support, and confirm the results of previous studies that transformational leadership has a positive and significant direct effect on innovative behavior with the research setting of the lecturers of private higher education in Indonesia. Thus, these findings are consistent, support and confirm the results of previous studies that transformational leadership has a positive and significant direct effect on innovative behavior. 


\subsection{Indirect Effect of Transformational Leadership on Performance with Innovative Behavior Mediation}

The results of this study also found that transformational leadership has a positive and significant indirect effect on performance by mediating innovative behavior. This shows that the transformational leadership pattern of higher education which is thick with idealized influence, inspirational motivation, intellectual stimulation, and individualized consideration can encourage the emergence of innovative behavior in the form of opportunity exploration, generativity, informative investigation, championing, and application, and then has implications for increasing performance manifested in persisting with enthusiasm and exerting extra effort as necessary to complete one's task activities successfully; volunteering to carry out task activities that are not formally part of the job; helping and cooperating with others; following organizational rules and procedures; and endorsing, supporting, and defending organizational objectives (Aguinis, 2013). This result is consistent with the results of testing the other two previous hypotheses and is inline by aligning and confirming the results of previous studies which prove that transformational leadership has a direct effect on innovative behavior (e.g. Park, Moon, \& Hyun, 2014; Han, et al., 2016; Bednall, et al., 2018; Ahmad, Easa, \& Mostapha, 2019) and innovative behavior has a direct effect on performance (e.g. Janssen, van de Vliert, \& West, 2004; Marques \& Ferreira, 2009; Gunday, et al., 2011; Aryee, et al., 2012; Bhanugopan, van der Heijden, \& Farrell, 2017; Schuh, et al., 2018; and Shanker, et al., 2019). Thus, these findings are consistent, support and confirm the results of previous studies that transformational leadership has a positive and significant indirect effect on performance by mediating innovative behavior.

\subsection{Indirect Effect of Talent Management on Performance with Innovative Behavior Mediation}

The results of this study also prove that talent management has a positive and significant indirect effect on performance by mediating innovative behavior. This shows that when universities have and develop talent management which is reflected in the resourcing strategy, attraction, and retention policies and programs, talent audits, role development, talent relationship management, performance management, total reward, career management, and creating the best place to work can encourage the emergence of innovative behavior in the form of opportunity exploration, generativity, informative investigation, championing, and application, and then has implications for increasing performance manifested in persisting with enthusiasm and exerting extra effort as necessary to complete one's task activities successfully; volunteering to carry out task activities that are not formally part of the job; helping and cooperating with others; following organizational rules and procedures; and endorsing, supporting, and defending organizational objectives (Aguinis, 2013). This result is consistent with the results of testing the other two previous hypotheses and is inline by aligning and confirming the results of previous studies which prove that talent management has a direct effect on innovative behavior (e.g. Khaki, Khanzadeh, \& Rad, 2017; Olaka, Okafor, \& Ulo, 2018; Riaz, Xu, \& Hussain, 2018) and innovative behavior has a direct effect on performance (e.g. Janssen, van de Vliert, \& West, 2004; Marques \& Ferreira, 2009; Gunday, et al., 2011; Aryee et al., 2012; Bhanugopan, van der Heijden, \& Farrell, 2017; Schuh, et al., 2018; Shanker, et al., 2019). Thus, these findings are consistent, support and confirm the results of previous studies that talent management has a positive and significant indirect effect on performance by mediating innovative behavior.

\section{Conclusion}

The research has proven that transformational leadership and innovative behavior had a significant direct effect on performance, transformational leadership and talent management had a significant direct effect on innovative behavior, transformational leadership and talent management had a significant indirect effect on performance by mediating innovative behavior, and talent management had not a significant direct effect on performance. A fit research model has been accomplished about the effects of transformational leadership and talent management performance by mediating innovative behavior but requires verification through further research, especially to verify the effect of talent management on performance. These models open up opportunities for the use of this model as a reference by researchers and practitioners in developing models of performance and also be further developed and expanded into studies and projects to develop a performance that is more complex, holistic, and comprehensive by adding variables and other relevant indicators. Besides, these findings also indicate that performance improvements can be achieved by improving transformational leadership, talent management, and innovative behavior practices.

\section{Acknowledgments}

We are very grateful to the lecturers in Indonesia who volunteered to spend their time and full dedication to responding to every statement item in the questionnaire completely and perfectly so that it could be used as research material in this article. May this willingness and dedication be a contribution to the development of science that can seeding to civilization.

\section{References}

Aamodt, M.G. (2013). Industrial/organizational psychology: An applied approach, Belmont, CA: Thomson Learning, Inc., 2013. 
Abuzaid, A.N., Al-Ma'aitah, N., Al-Haraisa, Y.E., \& Al-Tarawneh, K.I. (2019). Examining the impact of transformational leadership on the strategic decision effectiveness of Jordanian Microfinance Companies. International Review of Management and Marketing, 9(2), 76-83.

Agbaeze, K.E., Monyei, E.F., \& Agu, O.A. (2017). Impact of talent management strategies on organizational performance in selected deposit money banks in Lagos State, Nigeria. International Research Journal of Management, IT \& Social Sciences, 4(2), 135-151.

Aguinis, H. (2013). Performance Management. New Jersey: Pearson Education, Inc.

Ahmad, S. A., Easa, N.F., \& Mostapha, N. (2019). The effect of transformational leadership on innovation: Evidence from Lebanese Banks. European Research Studies Journal, 12(4), 215-240.

Apoi, A., \& Latip, H.B.A. (2019). The impact of transformational leadership on employee reactions towards individual work performance: A conceptual paper. International Journal of Academic Research in Business and Social Sciences, 9(8), 4760.

Armstrong, M. (2009). A handbook of human resource management practice. London: Kogan Page.

Aryee, S., Walumbwa, F. O., Zhou, \& Hartnell, C. A. (2012). Transformational leadership, innovative behavior, and task performance: test of mediation and moderation processes. Human Performance Journal, 25(1), 1-25.

Aurangzeb, \& Bhutto, S. A. (1026). Influence of talent management in enhancing organization performance (Evidence from service sector companies in Pakistan). Industrial Engineering Letters, 6(6), 49-55.

Bass, B.M. \& Avolio, B.J. (1990). The implications of transactional and transformational leadership for the individual, team, and organizational development. Research in Organizational Change and Development, 4, 231-272.

Bateman, T. S., \& Snell, S. A. (2015). Management. Eleventh edition. New York: McGraw-Hill.

Bednall, B.C., Rafferty, A.E., Shipton, H., Sanders, K., \& Jackson, C.J. (2018). Innovative behavior: How much transformational leadership do you need? British Journal of Management, 00, 1-21.

Bibi, M. (2019). Impact of talent management practices on employee performance: an empirical study among healthcare employees. SEISENSE Journal of Management, 2(1), 22-32.

Brown, D.J., \& Keeping, L.M. (2004). Elaborating the construct of transformational leadership: the role of effect. The Leadership Quarterly, 16, 2005, 245-72.

Byars, L.L., Rue, L.W., \& Ibrahim, N.A. (2016). Human resource management. $11^{\text {th }}$ ed., New York: McGraw-Hill Education.

Carmeli, A., Meitar, R., \& Weisberg, J. (2006). Self-leadership skills and innovative behavior at work. International Journal of Manpower, 27(1), 75-90.

Chandrasekara, W. S. (2019). THE effect of transformational leadership style on employee's job satisfaction and job performance: A case of the apparel manufacturing industry in Sri Lanka, International Journal of Economics, Commerce and Management, 7(7), 385-391.

Chen, Y., Ning, R., Yang, T., Feng, S., \& Yang, C. (2018). Is transformational leadership always good for employee task performance? Examining curvilinear and moderated relationships. Frontiers of Business Research in China, 12(22), 228.

Cingöz, A., \& Akdogan, A.A. (2011). An empirical examination of performance and image outcome expectations as determinants of innovative behavior in the workplace. Procedia Social and Behavioral Sciences, 24, 847-853.

Collings, D. G., \& Mellahi, K. (2009). Strategic talent management: A review and research agenda. Human Resource Management Review, 19, 304-313.

Colquitt, J. A., Lepine, J. A., \& Wesson, M. J. (2015). Organizational behavior: improving performance and commitment in the workplace, $4^{\text {th }}$ ed., New York: McGraw Hill Education Limited.

Gi-Ryun Park, G., Moon, G., \& Hyun, S. (2014). An impact of self-leadership on innovative behavior in sports educators and understanding of advanced research. The SIJ Transactions on Industrial, Financial \& Business Management (IFBM), 2(3), $117-122$

Gooty, J., Gavin, M., Johnson, P.D., Frazier, M.L., \& Snow, D.W. (2009). In the eyes of the beholder: Transformational leadership, positive psychological capital, and performance. Journal of Leadership and Organizational Studies, 15(4), 353-367.

Gunday, G., Ulusoy, G., Kilic, K., \& Alpkan, L. (2011). Effects of innovation types on firm performance. International Journal of Production Economics, 133(2), 662-676.

Hair, J.F., Balck, W. C., Babin, B. J., \& Anderson, R.E. Multivariate data analysis. 7th edition. Boston: Pearson.

Han, S., Seo, G., Yoon, S. \& Yoon, D. (2016). Transformational leadership and knowledge sharing: Mediating roles of employee's empowerment, commitment, and citizenship behaviors. Journal of Workplace Learning, 28(3), $130-149$.

Hatum, A. (2010). Next-Generation Talent Management: Talent Management to Survive Turmoil. Hampshire: Palgrave McMillan.

Hitu. (2018). Impact of talent management practices on employees' performance in the private sector bank. International Journal of Management (IJM), 9(1), 16-21.

Ivancevich, J. M., Konopaske, R., \& Matteson, M. T. (2014). Organizational behavior \& management, tenth edition. New York: McGraw Hill Education.

Janssen, O., van de Vliert, E., \& West, M. (2004). The bright and dark sides of individual and group innovation: A special issue introduction. Journal of Organizational Behavior, 25, 129-145.

Jyoti, J., \& Bhau, S. (2015). Impact of transformational leadership on job performance: Mediating role of leader-member exchange and relational identification, SAGE Open, 1-13. 
Kala'lembang, A., Soetjipto, B. E., \& Sutrisno (2015). The effect of transformational leadership and organizational culture on employee's working performance through organizational commitment, IJABER, 13(7), 5305-5322.

Kehinde, J. S. (2012). Talent management: Effect on organizational performance. Journal of Management Research, 4(2), 178-186.

Khaki, I., Khanzadeh, H. E., \& Rad, A.B. (2017). Talent management and innovative behavior based on the mediating role of organizational learning. International Letters of Social and Humanistic Sciences, 79, 16-28.

Kleysen, R. F., \& Street, C.T. (2001). Toward a multi-dimensional measure of individual innovative behavior. Journal of Intelectual Capital, 2(3), 284-296.

Kreitner, R., \& Kinicki, A. (2010). Organizational behavior: key concepts, skills \& best practices. New York: McGraw-Hill Irwin.

Lewis, R. E. \& Heckman, R. J. (2006). Talent management: A critical review. Human Resource Management Review, 16, $139-154$.

Li, H., Sajjad, N., Wang, Q., Ali, A.M., Khaqan, Z., \& Amina, S. (2019). Influence of transformational leadership on employees' innovative work behavior in sustainable organizations: Test of mediation and moderation processes. Sustainability, 11(1594), 1-22.

Marques, C. S., \& Ferreira, J. (2009). SME innovative capacity, competitive advantage, and performance in a traditionally industrial region of Portugal. Journal of Technology Management Innovation, 4(4), 53-68.

Ndolo, F.M., Kingi, W.K., \& Ibua, M.P. (2017). Effect of talent management practices on employee performance among commercial based state corporations in Kenya. International Journal of Management and Commerce Innovations, 5(1), 580-591.

Olaka, L. O. M., Okafor, L. C., \& Ulo, F. U. (2018). Talent management and innovation in indigenous hotels in Port Harcourt, Rivers State. IOSR Journal of Business and Management (IOSR-JBM), 20(3), 31-40.

Redford, K. (2005). Shedding light on talent tactics. Personnel Today, 26, 20-22.

Riaz, S., Xu, Y., \& Hussain, S. (2018). Understanding employee innovative behavior and thriving at work: A Chinese perspective. Administrative Science 8(46), 1-14.

Rizki, M., Parashakti, R.D., \& Saragih, L. (2019). The effect of transformational leadership and organizational culture towards employees' innovative behavior and performance. International Journal of Economics and Business Administration, 7(1), 227-239.

Schuh, S. C., Zhang, X., Morgeson, F.P., Tian, P., \& van Dick, R. (2018). Are you really doing good things in your boss's eyes? Interactive effects of employee innovative work behavior and leader-member exchange on supervisory performance ratings. Hum Resour Manage. 57(39), 7-409.

Shanker, R., Bhanugopan, R., van der Heijden, B. I.J.M., \& Farrell, M. (2017). Organizational climate for innovation and organizational performance: The mediating effect of innovative work behavior. Journal of Vocational Behavior, 100, 6777.

Shih, H.A., \& Susanto, E. (2011) Is innovative behavior really good for the firm? Innovative work behavior, conflict with coworkers and turnover intention: moderating roles of perceived distributive fairness. International Journal of Conflict Management, 22, 111-130.

Smilansky, J. (2006). Developing Executive Talent. New Jersey: John Wiley \& Sons Ltd

Son, J., Park, O., Bae. J., \& Ok, C. (2018). Double-edged effect of talent management on organizational performance: the moderating role of HRM investments. The International Journal of Human Resource Management, 1-29.

Supraptiningsih, Payangan, O., Brasit, N., \& Mardiana, R. (2018). Effects of talent management, leadership style and motivation on employee performance in information technology industries in West Jakarta and West Java, Indonesia. Scientific Research Journal (SCIRJ), 6(11), 20-26.

Vosloban, R.I. (2012). The influence of the employee's performance on the company's growth - a managerial perspective. Procedia Economics and Finance 3, $660-665$.

Widodo. (2019). Metodologi penelitian populer dan praktis. Depok: Rajawali Pers.

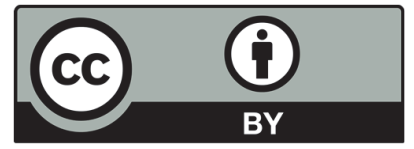

(C) 2020 by the authors; licensee Growing Science, Canada. This is an open access article distributed under the terms and conditions of the Creative Commons Attribution (CC-BY) license (http://creativecommons.org/licenses/by/4.0/). 